\title{
Colorectal Cancer pT4b TNM Finding v8
}

National Cancer Institute

\section{Source}

National Cancer Institute. Colorectal Cancer pT 4b TNM Finding v8. NCI Thesaurus. Code C134165.

Colorectal cancer with tumor directly invading or adhering to adjacent organs or structures. (from AJCC 8th Ed.) 